\title{
The Effectiveness Of Scraps-Made Realia For Teaching Speaking For The First Graders (An Experimental Study Conducted At Sd 1 Pedes)
}

\author{
Antika Septiana Puji Lestari ${ }^{1}$. Agustinus Hary Setyawan ${ }^{2}$ \\ English Education Department, Faculty of Teacher Training and Education \\ Mercu Buana University of Yogyakarta, Indonesia \\ email: ${ }^{1}$ antikaseptianapl@gmail.com, ${ }^{2}$ agustinushary@gmail.com
}

\begin{abstract}
There were many students that had problem in their speaking ability. Based on the problem, this research aims to: (1) Find out the result of students' learning speaking by using scraps-made realia; (2) Find out the result of students' learning speaking without using scraps-made realia; (3) Define the students' achievement in learning speaking by using scraps-made realia. This research involved class 1A and class 1B of SD 1 Pedes which have 44 students for each class. The researcher used pre-test and post-test to analyze the students' achievement in speaking skill. It was found that the mean of pre-test was 50 while the mean of post-test was 77,27. The obtained data of the t-test result was 27,447 . It means that $t$-test was higher than t-table $(27,447>2,018)$. It means that the post-test was higher than pretest. In conclusion, the finding of this research showed that teaching speaking by using scraps-made realia was effective to teach speaking skill. Hence, the researcher suggested to use scraps-made realia as alternative media in teaching speaking.
\end{abstract}

Keywords: Speaking, Realia, Scraps, Experimental

\section{INTRODUCTION}

English is the important language that people use in the world. It is because language is a tool for communication among nations in all over the world. In English learning, learner needs to master four language skills. Those are listening, speaking, reading and writing. Harmer (1989, p.16). Ur (1990, p.120) states that "of all four skills, speaking seems intuitively the most important". In addition, by mastering speaking skill, people can carry on conversations with others, and to exchange ideas with others.

Every day, many Indonesian communicate with others, but almost all of them are not using English language. Based on the explanations above, it can be concluded that language is about what we looked, felt, and thought. Richards (2008, p.19) states that "the mastery of speaking in English is a priority for many second-language or foreign-language learners". It means speaking 
is the best skill in learning language because we can communicate by speaking. Speaking skill is a mental concept processed by someone in such a way to form a meaning when it is uttered.

Bailey (2005) and Goh (2007) state that "speaking has proposed methods to enhance speaking skills by means of syllabus design, teaching principles, types of tasks and materials, and speaking assessment". In other words, speaking is necessary to be practiced continuously although students sometimes find a problem when they practice to speak in English. Therefore if the teachers want their students to speak well and correctly, the teacher needs to frequently accustom students to speak in English especially in Elementary School.

The researcher doing interview with the teacher at SD 1 Pedes before doing observation at SD 1 Pedes, the researcher found that the teacher had not invited the students to get used with English in their learning process. In learning activity, the teacher always used flashcard or drew pictures on blackboard and he only asked the students to mention the name of pictures. As the result, the students are more fun to play alone and disturb another student who are also playing. In the opposite case when the teacher gave a game to guess the name from provided images they became very enthusiastic.

Based on the problem above, the researcher provided a scraps-made realia. It aims to overcome those problems. By scraps-made realia, the teacher can make various shapes game with the material to be taught. By the scraps-made realia, the students can get more enthusiastic in English learning process. They can more speak in classroom, because they like kind of real object. Finally, they can easily remember the lesson. Herrell \& Jordan (2000, p.23) says that "if the real thing is not available, the teacher must move down the continuum from the concrete (real thing), to a replica such as model, to a semiconcrete object such as a photograph or illustration". It means that realia as a real object hopefully can help the students in learning process.

Referring the reason written above, the researcher decided that scraps-made realia as media in teaching speaking skill at SD 1 Pedes because scraps-made realia make students achievement in speaking competence.

\section{Research Method}

The researcher conducted an experimental research. The researcher used Quasi Experimental Design. This design involved experimental group and control group that selected purposively (purposive sampling). It meant that all of the students who was available in the research setting was treated as the research subject. In teaching speaking, the researcher using scraps-made realia as media at the experimental class and without using scrapsmade realia at the control class.

The researcher used interview, observation, test and documentation as instruments to collage the data. The researcher did interview for need analysis with the English 
teacher, after doing interview, the researcher did observation while learning process in first graders and then did interview with some of the students in first graders. The interview guidelines was used in collecting the data. After that, the researcher went to another school in same level to check validity of instrument. After getting the result of test validity, the researcher backed to school to provide pre-test in $1 \mathrm{~A}$ and $1 \mathrm{~B}$ classes to find the students speaking ability in speaking. The data was collected by giving oral test.

The implementations is the researcher provided treatment by using scraps-made realia in experimental class, whereas control class without scraps-made realia. After three treatments, the researcher provided post-test both of the classes to find the effectiveness after getting treatment. The last steps, the researcher collected the data, then the researcher calculated the data, after that the researcher analyzed the data and the last was drawing conclusion.

The formula to calculate the mean, standard deviation and t-test are stated as follows:

\section{Mean}

The arithmetic average was calculated when grading classroom test. The formula is as follow:

$$
\bar{x}=\frac{\sum x}{N}
$$

$\begin{array}{ll}\bar{x} & : \text { mean } \\ \Sigma & : \text { sum of score } \\ \mathrm{N} & : \text { number of students }\end{array}$

The mean of score is will use as one of the parameters of the effectiveness the result of test.

\section{Standard Deviation}

The formula of standard deviation is as follows:

$$
\mathrm{SD}=\sum_{X} 2-\frac{\left(\sum_{X}\right) 2}{N}
$$

SD : standard deviation

$\sum \mathrm{x}^{2} \quad$ : the sum of gain result

$\mathrm{N}$ : number of sample

3. The T-test

Formula of T-test is:

$$
\begin{array}{ll}
\mathrm{t}=\frac{M x-M y}{\sqrt{\left(\frac{\sum_{X} 2+\sum_{Y}^{2}}{N x+N y-2}\right)\left(\frac{1}{N x}+\frac{1}{N y}\right)}} \\
\text { Notes: } \\
\mathrm{Mx} \quad: \text { mean of control class } \\
\mathrm{N} \quad: \text { number of sample } \\
\mathrm{X} \quad: \text { deviation of } \mathrm{x} \text { ss } \\
\mathrm{Y} \quad: \text { deviation of } \mathrm{y}
\end{array}
$$

The degree of freedom:

$\mathrm{df}=(\mathrm{Ne}+\mathrm{Nc}-2)$

$\mathrm{df}=$ degree of freedom

$\mathrm{Ne}=$ the number of experimental group

$\mathrm{Nc}=$ the number of control class

With the hypothesis statistic as follows:

If t-calculation > t-table: Ho rejected and Ha accepted 
If t-calculation < t-table: Ho accepted and Ha rejected

Finding and Discussions

The Result of Students Learning Speaking by Using Scraps-Made Realia

The researcher used post-test as the result achievement of the students learning speaking by using scraps-made realia. The purpose of giving post-test was to find out the students speaking skill ability after getting treatments. The post-test was conducted on June, $14^{\text {th }} 2016$ for experimental class (1B). There were 22 students in experimental class (1B). The post-test was conducted in form of oral test as a different with pre-test.

Table 4.5 Post-test Score of Experimental Class

\begin{tabular}{cccccc}
\hline No. & Students & Score & No. & Students & Score \\
\hline 1 & $\mathrm{X}_{1}$ & 64 & 12 & $\mathrm{X}_{12}$ & 72 \\
2 & $\mathrm{X}_{2}$ & 80 & 13 & $\mathrm{X}_{13}$ & 76 \\
3 & $\mathrm{X}_{3}$ & 14 & $\mathrm{X}_{14}$ & 80 \\
4 & $\mathrm{X}_{4}$ & 76 & 15 & $\mathrm{X}_{15}$ & 68 \\
5 & $\mathrm{X}_{5}$ & 16 & $\mathrm{X}_{16}$ & 76 \\
6 & $\mathrm{X}_{6}$ & 68 & 17 & $\mathrm{X}_{17}$ & 84 \\
7 & $\mathrm{X}_{7}$ & 72 & 18 & $\mathrm{X}_{18}$ & 92 \\
8 & $\mathrm{X}_{8}$ & $\mathrm{X}_{9}$ & 19 & $\mathrm{X}_{19}$ & 76 \\
9 & $\mathrm{X}_{10}$ & 88 & 20 & $\mathrm{X}_{20}$ & 72 \\
10 & $\mathrm{X}_{11}$ & 88 & 21 & $\mathrm{X}_{21}$ & 80 \\
11 & 80 & 22 & $\mathrm{X}_{22}$ & 72 \\
\hline
\end{tabular}

Based on the table 4.5, the researcher found that the highest score was 92 and the lowest score was 64. In conclusion, the result showed the effectiveness in experimental class which the mean score was higher than the criteria of minimum completeness (KKM); The criteria of minimum completeness (KKM) was 75. Based on the students' post-test result, there were $68 \%$ of 22 students or 15 students who passed the criteria of minimum completeness (KKM).

\section{The result of Students Learning Speaking without Using Scraps-Made Realia \\ Post-test was conducted on June, $17^{\text {th }} 2016$} for control class (1A). There were 22 students in control class $(1 \mathrm{~A})$. The post-test was conducted 
in form of oral test as the different with pre-test. The post-test was given after giving treatments without using scraps-made realia. The purpose of giving post-test was to find out the students speaking skill after got treatments.

Table 4.8 Post-Test Score of Control Class

\begin{tabular}{cccccc}
\hline No. & Students & Score & No. & Students & Score \\
\hline 1 & $\mathrm{C}_{1}$ & 84 & 12 & $\mathrm{C}_{12}$ & 76 \\
2 & $\mathrm{C}_{2}$ & 72 & 13 & $\mathrm{C}_{13}$ & 72 \\
3 & $\mathrm{C}_{3}$ & 80 & 14 & $\mathrm{C}_{14}$ & 68 \\
4 & $\mathrm{C}_{4}$ & 76 & 15 & $\mathrm{C}_{15}$ & 72 \\
5 & $\mathrm{C}_{5}$ & 88 & 16 & $\mathrm{C}_{16}$ & 76 \\
6 & $\mathrm{C}_{6}$ & 80 & 17 & $\mathrm{C}_{17}$ & 68 \\
7 & $\mathrm{C}_{7}$ & 72 & 18 & $\mathrm{C}_{18}$ & 80 \\
8 & $\mathrm{C}_{8}$ & 76 & 19 & $\mathrm{C}_{19}$ & 76 \\
9 & $\mathrm{C}_{9}$ & 80 & 20 & $\mathrm{C}_{20}$ & 80 \\
10 & $\mathrm{C}_{10}$ & 64 & 21 & $\mathrm{C}_{21}$ & 72 \\
11 & $\mathrm{C}_{11}$ & 72 & 22 & $\mathrm{C}_{22}$ & 68 \\
\hline
\end{tabular}

Based on the table 4.8, post-test score of control class result, it could be seen that the highest score was 88 and the lowest score was 64 . In conclusion, the result showed the effectiveness in experimental class which the mean score was higher than the criteria of minimum completeness (KKM); The criteria of minimum completeness (KKM) was 75. Based on the students' post-test result, there were $55 \%$ of 22 students or 12 students who passed the criteria of minimum completeness (KKM).

The Effectiveness of Teaching Speaking by Using Scraps-Made Realia

In finding the effectiveness of teaching speaking by using scraps-made realia, the researcher analyzed between pre-test and post-test both of two classes.

\section{Pre-Test and Post-Test experimental classes}

Pre-test and post-test was conducted by the researcher to both experimental classes. After having the pre-test scores of each respondent, the average of the scores was calculated through the statistical calculation s follow:

a) Hypothesis used in t-calculation was:

If t-calculation > t-table: Ho rejected and $\mathrm{Ha}$ accepted

If $\mathrm{t}$-calculation < t-table: Ho accepted and $\mathrm{Ha}$ rejected

Before conducting a statistical analysis, the alternative hypothesis and hypothetical value 
need to be formulated first in order to help the researcher in reading the conclusions from the results of statistical tests. In determining, the hypothesis should be:

1. Declare the relationship

2. In accordance with the facts

\section{Simple}

4. able to explain the facts

b) The score of the significance level chosen was $\alpha=0,05$

After formulating hypotheses that was used, the next step was determining the value of the significance level that would be chosen. Normally, in testing statistical analysis using the confidence level used is $95 \%$, then its alpha value of 0.05 .

c) Tester's statistic

$$
\mathrm{t}_{\text {calculation }}=\frac{M x-M y}{\sqrt{\left(\frac{\sum_{X} 2+\sum_{Y} 2}{N x+N y-2}\right)\left(\frac{1}{N x}+\frac{1}{N y}\right)}}=27,447
$$

with free degree $k=\left(n_{1}+n_{2}-2\right)=42$

After determining its alpha value of 0.05 , the next step is determining the statistical testing for the formula used to determine the $t$ test calculated using the formula polled variance. However, this study used the $t$ test with SPSS then the formula as a picture to complete manually. In order to determine table t test, it must be looked for the degree of free samples of it, so that it can be processed by excel.

d) Decision making

because score $t_{\text {calculation }}=27,447>$ $2,018=t_{\text {tabel }}$ and it was found the score Sig. $0,00<0,05$ so $\mathrm{H}_{0}$ was refused.
After the data was tested, the researchers then took a decision by seeing the steps above. When determining $t$ calculation have done with SPSS, the further step was defined $t$ table by excel. In the Excel, enter the formula = TINV (alpha value, equivalent free) then the data okay can be obtained. Taking decision if $\mathrm{t}$ table was bigger than $t$ calculation and sig. was smaller than alpha then $\mathrm{H}_{0}$ was rejected.

e) Conclusion

$\mathrm{H}_{0}$ was refused mean, there were significance difference mean score of pre-test and post-test score of eksperimental class.

In the last step, it could be concluded that if $\mathrm{H}_{0}$ was rejected so there was significant mean difference from the two data.

\section{Conclusion}

Based on finding and discussion, it can be concluded as follows: First, the researcher found the enhanced of students score after getting treatment by using scraps-made realia. The result shows that the mean of pre-test was 50 while the mean of post-test was 77,27 . It can be said that score achieved the criteria of minimum completeness (KKM) was 75 .

Second, the researcher found that the mean score of control class who taught without using scraps-made realia also got enhanced. But, the achievement was not higher than the experimental class. The result shows that the average of pre-test was 48 while the average of post-test was 76. Third, the effectiveness of teaching speaking by using scraps-made realia 
was calculated the t-test score in both of classes, it showed that there was a significant difference between experimental class and control class. The students of the experimental class gained better average score than students of the control class. It can be proved from the result of t-test between experimental class and control class. The obtained data of the result of t-test was 27,447 . It means that $\mathrm{t}$-test was higher than t-table $(27,447>2,018)$. Therefore, the researcher concluded that Ho was accepted and $\mathrm{Ha}$ was rejected.

\section{Suggestions}

Based on conclusion above, the researcher would like to give some suggestions which may be useful for the teacher, school, and other relevant researchers. The teacher should use scraps-made realia as a media in teaching of speaking, because the media was effective to teach speaking skill. By using scraps-made realia, the students will not get bored in English teaching learning process, because the students can interact and see directly the media. Here, this research finding was to launch the new policy for the teacher to vary their media in teaching learning process. The researcher hopes the next researcher can use this finding as a reference to conduct their research on the same field. It is really possible that there is another more effective way to teach speaking.

\section{References}

Harmer, Jeremy. (1989). The Practice of English Language Teaching. England: Pearson Education Limited.

Ur, Penny. (1990). The Practice of Language Teaching Practice and Theory. Cambridge: Cambridge University Press.

Richard, J. C. (2008). Teaching Listening and Speaking from Theory to Practice. USA: Cambridge University Press.

Goh, C. (2007). Teaching speaking in the language classroom. Singapore: SEAMEO Regional Language Centre.

Bailey, K.M. (2005). Practical English Language Teaching: Speaking. New York: McGraw-Hill. Faculty of Arts. 2004. Undergraduate catalog. Nakhon Pathom, Thailand: SilpakornUniversity Press.

Herrell, Adrienne and Michael, Jordan. (2000). Fifty Strategies For Teaching English Language Learners (Second ed). New Jersey:Pearson Education, Inc.https://www.vocabulary.com/diction ary/scrap. [Accessed March 25 ${ }^{\text {th }}$ 2016] 